\title{
A dual-fuel compression ignition engine - distinctive features
}

\begin{abstract}
For many years in the Department of Automobiles and Internal Combustion Engines in Technical University of Radom there are carried out investigations on dual-fuel compression ignition engine in which the ignition is initiated by a pilot diesel oil dose and the applied main fuels have properties similar to those applied in spark ignition engines. The tested fuels were methanol, ethanol, LPG and natural gas. Analysis of the obtained results allowed to make some generalizations and to determine advantages as well as problems which should be solved for higher efficiency, power and durability.

The paper will present information on efficiency, power, toxic exhaust emission and chosen parameters of combustion process of a dual-fuel compression ignition engine as well as on a difficult to control - knock combustion which may result in lower engine durability and piston crank mechanism failure.
\end{abstract}

Key words: dual fuel compression ignition engine, combustion process parameters, emission, knocking combustion

\section{Dwupaliwowy silnik o zapłonie samoczynnym - cechy charakterystyczne}

\begin{abstract}
W Zakładzie Pojazdów i Silników Spalinowych Politechniki Radomskiej od kilkunastu lat prowadzone sa badania dwupaliwowego silnika o zapłonie samoczynnym, w którym zapłon realizowany jest od inicjujacej dawki oleju napędowego, zaś jako paliwa główne wykorzystane były różne paliwa o właściwościach zbliżonych do stosowanych w silnikach o zaptonie iskrowym. Paliwami tymi byly: alkohol metylowy, alkohol etylowy, gaz propan-butan, gaz ziemny. Analiza dotychczasowych wyników badań pozwolita na dokonanie pewnych uogólnień i sformułowanie cech pozytywnych wyróżniających badany silnik, ale także problemów, które należy rozwiąać, by silnik cechowat się duża sprawnością, moca oraz trwatościa.

W referacie przedstawione zostana informacje na temat sprawności takiego silnika, jego mocy, zawartości sktadników toksycznych w spalinach, wybranych parametrów procesu spalania, a także o trudnym do opanowania zjawisku spalania stukowego prowadzacym do obniżenia trwałości czy też awarii układu tłokowo-korbowego.

Słowa kluczowe: dwupaliwowy silnik o ZS, parametry procesu spalania, emisja, spalanie stukowe
\end{abstract}

\section{Introduction}

Nowadays, compression ignition engine is the most widespread source of drive in automotive vehicles and engine generators due to its high overall efficiency and favourable exhaust emission. Emerging reports on crude oil depletion [1] result in increased interest in investigation on other non-standard fuels for this type of engine and the system of dual-fuelling [2-9, 11-13]. For many years in the Department of Automobiles and Internal Combustion Engines in Technical University of Radom there are carried out investigations on dual-fuel compression ignition engine in which the main fuel were: methanol, ethanol, LPG and natural gas. Each time, ignition was initiated by a pilot diesel oil dose. The overall scheme of such system of fuelling is presented in Fig. 1.

In the initial phase of investigation, practical considerations, i.e. small modifications of the engine (with the possibility to return to the standard fuelling mode - with diesel oil only) spoke for the choice of such idea of fuelling system solution.

An important reason was also an expectation of improvement in the overall efficiency of such fuelled engine due to some common features of the applied fuelling system and often and often described in the literature HCCI (homogeneous-charge compression ignition) system [10]. It regards fast development of combustion of the main fuel

\section{Wstęp}

Tłokowy silnik spalinowy o zapłonie samoczynnym ze względu na dużą wartość sprawności ogólnej oraz korzystny skład spalin jest obecnie najbardziej rozpowszechnionym źródłem napędu pojazdów samochodowych a także różnego rodzaju agregatów stacjonarnych. Pojawiające się przewidywania mówiące o zmniejszeniu zasobów ropy naftowej [1] powodują, że coraz częściej prowadzone są badania i próby zastosowania innych, nietypowych dla tego silnika paliw z wykorzystaniem dwupaliwowego systemu zasilania [2-9, 11-13]. W Zakładzie Pojazdów i Silników Spalinowych od szeregu lat prowadzone są badania dwupaliwowego silnika o zapłonie samoczynnym, w którym jako paliwo główne stosowane były: alkohol etylowy, mieszanina propan-butan, gaz ziemny. Inicjacja zapłonu realizowana była każdorazowo od dawki oleju napędowego.

Ogólną ideę takiego systemu zasilania przedstawia rys. 1 .

Za przyjęciem wyżej przedstawionej koncepcji rozwiązania układu zasilania przemawiały w początkowej fazie prowadzenia badań przede wszystkim względy praktyczne, tj. niewielki zakres przeróbek silnika bazowego, z możliwością szybkiego powrotu do zasilania standardowego (jedynie olejem napędowym).

Ważną przesłanką były także przewidywania dotyczạce możliwości poprawy sprawności tak zasilanego silnika 


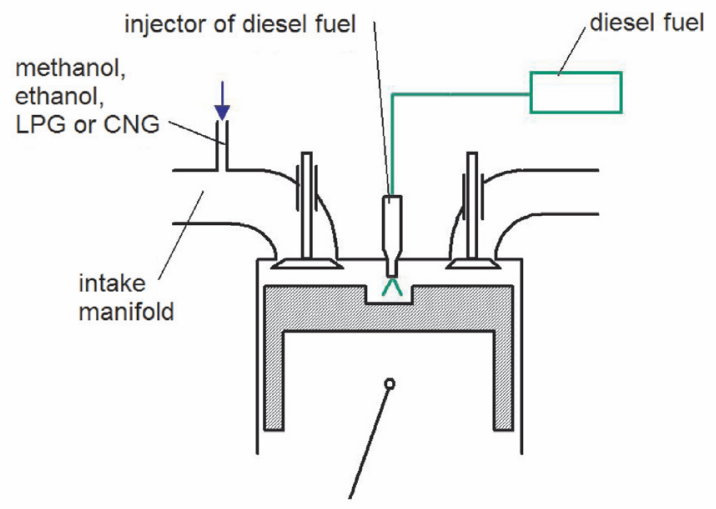

Fig. 1. Dual-fuel compression ignition engine with the ignition of the main fuel-air homogeneous mixture initiated by pilot diesel oil dose

Rys. 1. Silnik dwupaliwowy o zapłonie samoczynnym z zapłonem homogenicznej mieszaniny paliwa głównego i powietrza od inicjujacej zapłon dawki oleju napędowego

- air homogeneous mixture in the substantial part of the combustion chamber as a result of an ignition initiated by the sprayed and diffused pilot diesel oil dose.

Some distinctive features that appeared regardless of the applied fuel were observed carrying out investigation on the described solution with the application of various main fuels.

To describe these features the paper presents obtained investigation results regarding the following three various fuelling modes:

a) with the use of evaporated methanol with a mixer in the intake manifold,

a)

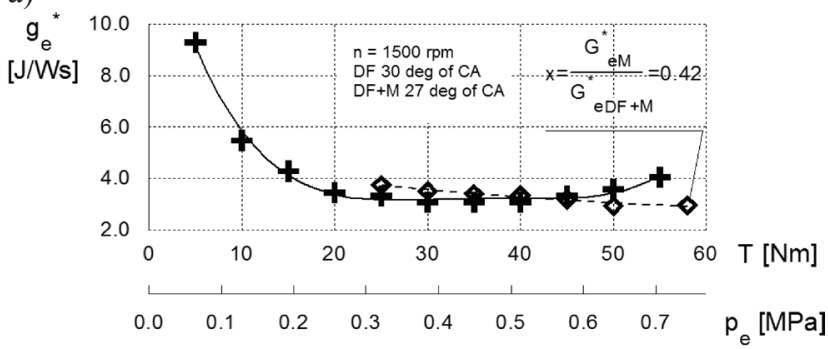

b)

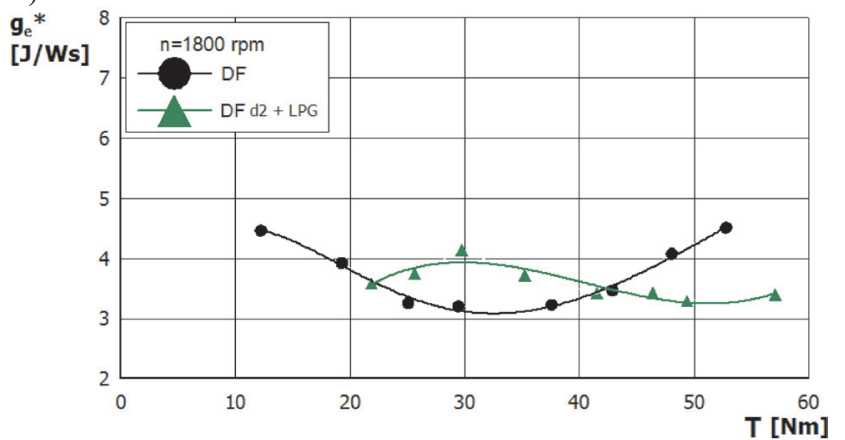

ze względu na pewne wspólne cechy przyjętego systemu spalania do coraz częściej opisywanego systemu HCCI (homogeneous-charge compression ignition) [10]. Dotyczy to szybkiego rozwoju procesu spalania homogenicznej mieszaniny powietrza i paliwa głównego - w dużej części komory spalania w wyniku zapłonu od rozpylonej i rozprowadzonej w komorze spalania dawki oleju napędowego.

W wyniku badań opisanego rozwiązania przy stosowaniu różnych paliw głównych zaobserwowano pewne charakterystyczne cechy występujące niezależnie od stosowanego paliwa głównego.

W niniejszym artykule dla opisania i przybliżenia tych cech wykorzystano wyniki badań dla trzech różnych sposobów zasilania:

a) z wykorzystaniem odparowanego alkoholu metylowego $\mathrm{z}$ mieszalnikowym systemem doprowadzenia tego paliwa,

b) z wykorzystaniem paliwa LPG z mieszalnikowym systemem doprowadzenia paliwa głównego,

c) w wykorzystaniem paliwa LPG z wtryskowym systemem doprowadzenia paliwa głównego.

\section{Charakterystyki obciążeniowe jednostkowego zużycia energii}

Wobec różnych wartości opałowych stosowanych paliw głównych zdecydowano się na sporządzenie charakterystyk obciążeniowych jednostkowego zużycia energii $\mathrm{g}_{\mathrm{e}}{ }^{*}[\mathrm{~J} / \mathrm{W} \cdot \mathrm{s}]$ $=\mathrm{f}(\mathrm{M})[\mathrm{N} \cdot \mathrm{m}]$, a nie jak to zwykle się wykonuje $\mathrm{g}_{\mathrm{e}}[\mathrm{g} / \mathrm{kW} \cdot \mathrm{h}]$ $=\mathrm{f}(\mathrm{M})[\mathrm{N} \cdot \mathrm{m}]$.

Na wykresach zamieszczonych poniżej zestawiono charakterystyki jednostkowego zużycia energii dla opisanych w rozdz. 1 przypadków zasilania a, b i c.

c)

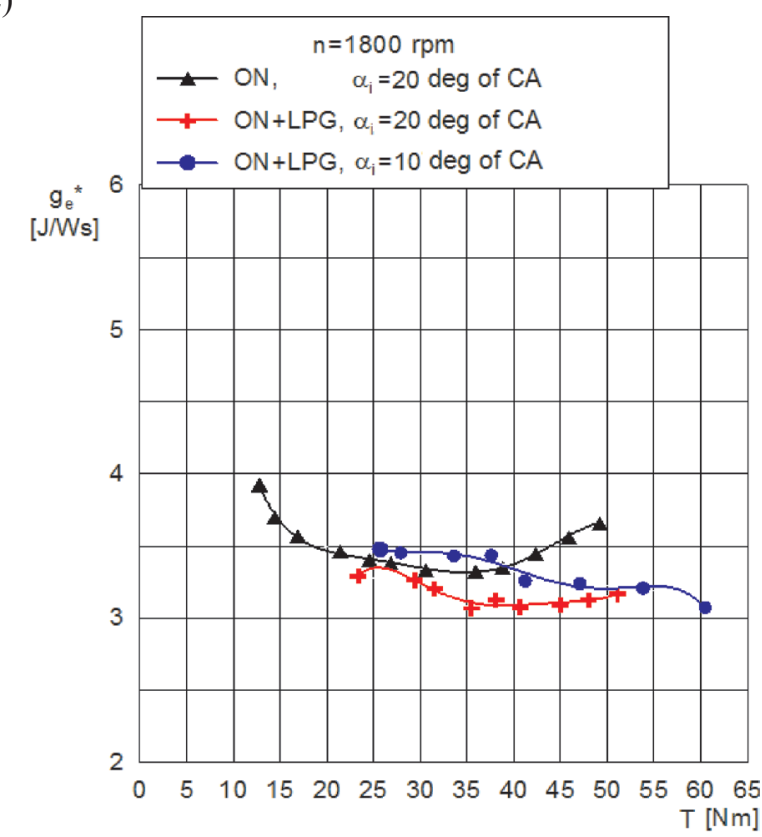

Fig. 2. Comparison of specific energy consumption $\mathrm{g}_{\mathrm{e}}{ }^{*}[\mathrm{~J} / \mathrm{W} \cdot \mathrm{s}]$ for a dual-fuel engine: a) engine fuelled mainly with methanol [9], b) engine fuelled mainly with LPG via a mixer [11], c) engine fuelled mainly with LPG via an injection into the intake manifold [12]

Rys. 2. Porównania jednostkowego zużycia energii $g_{e}^{*}[\mathrm{~J} / \mathrm{W} \cdot \mathrm{s}]$ przez silnik dwupaliwowy: a) silnik zasilany głównie metanolem [9], b) silnik zasilany głównie LPG poprzez mieszalnik [11], c) silnik zasilany głównie LPG poprzez wtrysk do kolektora dolotowego [12] 
b) with the use of LPG with a mixer in the intake manifold,

c) with the use of LPG with an injector in the intake manifold.

\section{Load characteristics of specific energy consumption}

Because of different heating values of the applied main fuels, the author decided to prepare load characteristics of specific energy consumption $\mathrm{g}_{\mathrm{e}}{ }^{*}[\mathrm{~J} / \mathrm{W} \cdot \mathrm{s}]=\mathrm{f}(\mathrm{T})[\mathrm{N} \cdot \mathrm{m}]$ and not, as usually presented $-\mathrm{g}_{\mathrm{e}}{ }^{*}[\mathrm{~g} / \mathrm{kW} \cdot \mathrm{h}]=\mathrm{f}(\mathrm{T})[\mathrm{N} \cdot \mathrm{m}]$.

Plots presented in Fig. 2 compare specific energy consumption characteristics for the fuelling modes $\mathrm{a}, \mathrm{b}$, and $\mathrm{c}$ described in chapter 1 .

Analysis of the plots presented in Fig. 2 shows that, for each of the applied fuels, it is possible to achieve maximum torque values higher than those achieved in the case of standard engine fuelling with simultaneous increase in the overall efficiency (specific energy consumption decrease), particularly over the range of full loads.

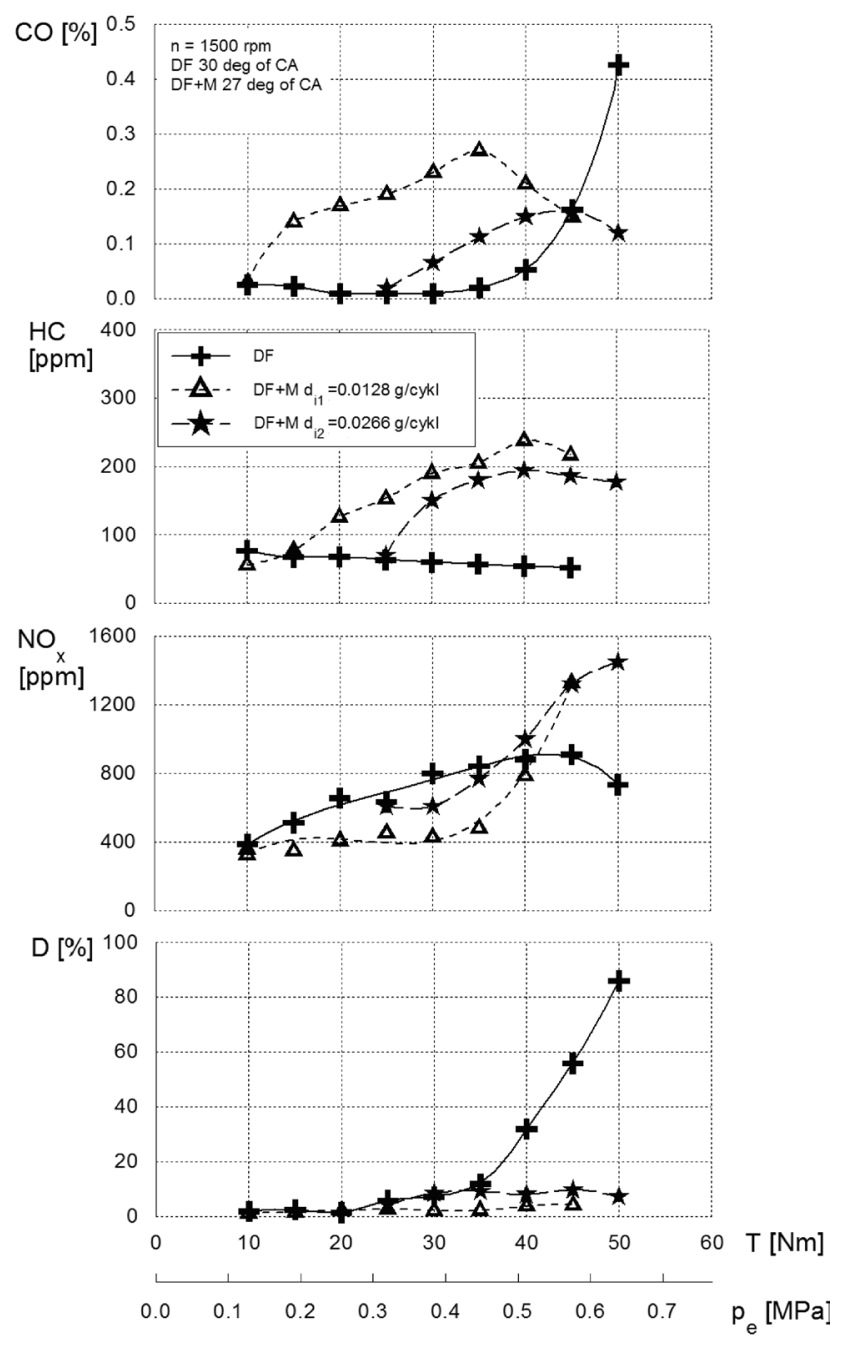

Fig. 3a. Emissions of principal pollutants and smoke level of the dualfuel engine fuelled mainly with methanol [9]

Rys. 3a. Zawartości podstawowych składników i zadymienia spalin silnika dwupaliwowego zasilanego głównie metanolem [9]
Analiza zamieszczonych wykresów wykazuje, że dla każdego ze stosowanych paliw można uzyskać wyższą wartość maksymalnego momentu obrotowego uzyskiwanego przez silnik zasilany dwupaliwowo w porównaniu z przypadkiem zasilania standardowego przy jednoczesnej poprawie sprawności ogólnej silnika (zmniejszeniu jednostkowego zużycia energii), szczególnie w obszarze obciążeń całkowitych.

Należy tutaj zwrócić uwagę na fakt, że osiągana wartości momentu obrotowego a także jednostkowego zużycia energii zależy wyraźnie od wartości inicjującej zapłon dawki oleju napędowego a także od regulacji kąta wyprzedzenia wtrysku tej dawki. Te dwie wielkości, jak to się okazało w wyniku dalszych analiz stają się ważnymi parametrami regulacyjnymi silnika dwupaliwowego.

Należy tu dodać, że wielkości te wywierają wpływ na położenie granicy spalania stukowego, które to zjawisko jest obserwowane przy dużych obciążeniach silnika.

\section{Charakterystyki obciążeniowe emisji podstawowych składników spalin}

W trakcie sporządzania charakterystyk obciążeniowych mierzono zawartość podstawowych składników spalin dla opisanych stosowanych paliw. Wyniki zestawiono na poniższych wykresach.

Analiza zamieszczonych na rys. 3 charakterystyk wykazuje, że dla każdego przypadku stosowanego paliwa daje się zaobserwować charakterystyczne przebiegi zawartości składników w spalinach, które można uogólnić poniższymi spostrzeżeniami:

- w silniku dwupaliwowym w porównaniu z przypadkiem zasilania standardowego obserwuje się wzrost emisji tlenku węgla $\mathrm{CO}$ w obszarze obciążeń częściowych i zmniejszenie zawartości tego związku w obszarze obciążeń maksymalnych,

- w silniku dwupaliwowym wzrost emisji węglowodorów w obszarze obciążeń częściowych i obniżenie emisji do wartości porównywalnych z przypadkiem zasilania standardowego przy obciążeniach zbliżonych do maksymalnych,

- w silniku dwupaliwowym obserwuje się obniżony poziom zawartości tlenków azotu $\mathrm{NO}_{\mathrm{x}} \mathrm{w}$ spalinach w obszarze obciążeń częściowych i uzyskanie wartości porównywalnych lub wyższych w porównaniu z przypadkiem zasilania standardowego w obszarze obciążeń całkowitych,

- silnik dwupaliwowy charakteryzuje się obniżeniem poziomu zadymienia spalin w porównaniu $\mathrm{z}$ wersją zasilaną standardowo.

\section{Podstawowe parametry procesu spalania}

W trakcie badań każdej wersji zasilania silnika dwupaliwowego dokonywano rejestracji przebiegu ciśnienia spalania w funkcji kąta obrotu wału korbowego $p=f(\alpha)$. Zarejestrowane przebiegi posłużyły do sporządzenia charakterystyk szybkości narastania ciśnienia w funkcji kąta obrotu wału korbowego, a te z kolei do sporządzenia charakterystyk zmienności maksymalnej wartości szybkości narastania ciśnienia $\mathrm{w}$ funkcji obciążenia $(\mathrm{dP} / \mathrm{d} \alpha)_{\max }$ $\left[\mathrm{MPa} /{ }^{\circ} \mathrm{OWK}\right]=\mathrm{f}(\mathrm{M})[\mathrm{N} \cdot \mathrm{m}]$. 

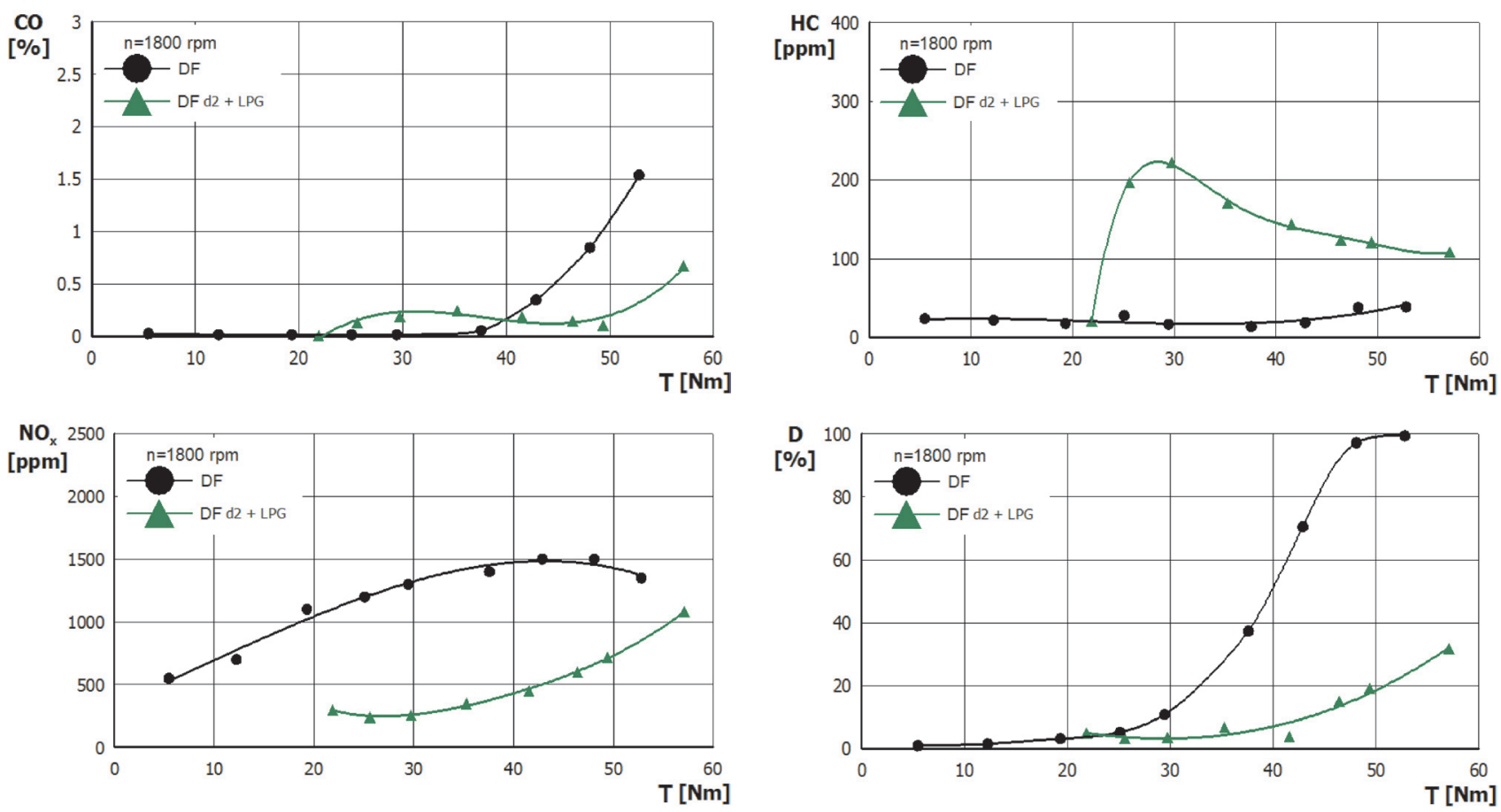

Fig. 3b. Emissions of principal pollutants and smoke level of the dual-fuel engine fuelled mainly with LPG via mixer [11]

Rys. 3b. Zawartości podstawowych składników i zadymienia spalin silnika dwupaliwowego zasilanego głównie LPG poprzez mieszalnik [11]

Particular attention should be payed here to the fact that the obtained torque and specific energy consumption values visibly depend on the pilot diesel oil dose quantity as well as on its injection timing. These two values, as it turned out in further analysis, become important regulation parameters of a dual-fuel engine.

It should be added that these values affect a location of the knock combustion limit. Phenomenon of knock combustion is observed at high engine loads.

\section{Load characteristics of principal pollutants emissions}

During preparation of load characteristics, emissions of principal pollutants were measured. The obtained results are given in the form of plots in Fig. 3a, 3b and 3c.

Analysis of the plots presented in Fig. 3 shows that, for each of the applied fuels, there may be observed characteristic runs of pollutants emissions which can be generalized with the following remarks:

- in a dual-fuel engine, in comparison to the standard fuelling mode, $\mathrm{CO}$ emission increases over the range of partial loads and decreases over the range of loads close to maximum;

- in a dual-fuel engine, $\mathrm{HC}$ emission increases over the range of partial loads and is comparable to that obtained for standard fuelling mode, over the range of loads close to maximum;
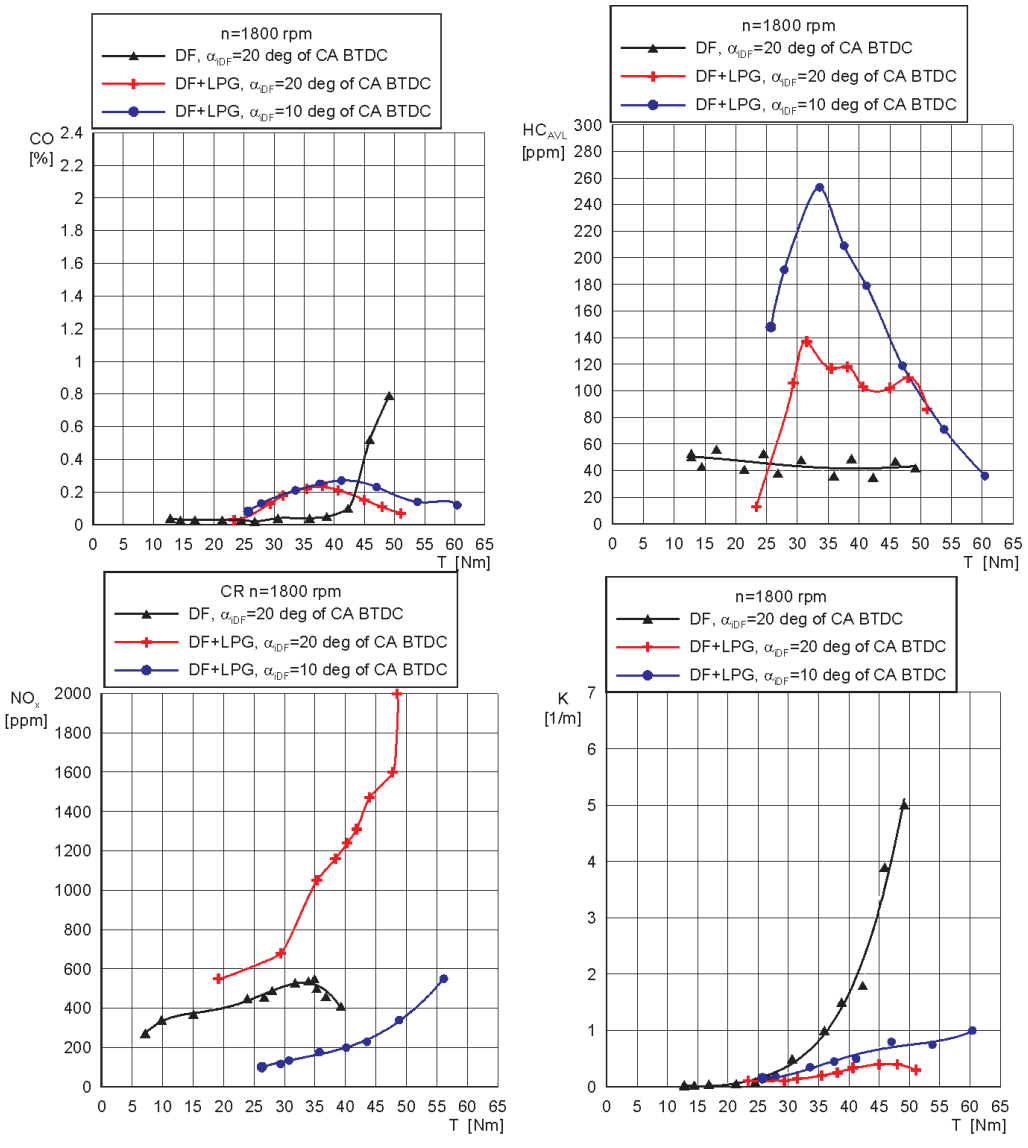

Fig. 3c. Emissions of principal pollutants and smoke level of the dual-fuel engine fuelled mainly with LPG via an injection into the intake manifold [12]

Rys. 3c. Zawartości podstawowych składników i zadymienia spalin silnika dwupaliwowego zasilanego glównie LPG poprzez wtrysk do kolektora dolotowego [12] 
- in a dual-fuel engine, $\mathrm{NO}_{\mathrm{x}}$ emission decreases over the range of partial loads and is comparable or higher to that obtained for standard fuelling mode, over the range of full loads;

- a dual-fuel engine is characterised by lower smoke level in comparison to the standard fuelling mode.

\section{Basic combustion process parameters}

During investigation, it was registered combustion pressure versus crankshaft angle $p=f(\alpha)$ for each fuelling version. The registered pressure courses served to prepare characteristics of the rate of pressure rise versus crankshaft angle and those, subsequently, to prepare variability characteristics of the maximum rate of pressure rise versus engine load $(\mathrm{dP} / \mathrm{d} \alpha)_{\max }\left[\mathrm{MPa} /{ }^{\circ} \mathrm{CA}\right]=\mathrm{f}(\mathrm{T})[\mathrm{N} \cdot \mathrm{m}]$. The registered characteristics are presented in Fig. 4.

Analysis of the presented courses of $(\mathrm{dP} / \mathrm{d} \alpha) \max$ indicates that, over the range of loads close to maximum, a dual-fuel engine is characterised by considerably higher (in some cases even over twice) values of this parameter in comparison to the standard fuelling mode.

It should be stressed that this effect is an undesirable consequence of the applied combustion system in which an homogeneous air - main fuel mixture starts the combustion process from the earlier initiated diesel oil dose combustion in a substantial part of the combustion chamber. This effect is clearly heard as a "pinging" sound. The occurrence of knocking combustion over the range of high load limits the possibility of further increase of the engine load. Knocking combustion becomes a limit for engine performances and is a dangerous phenomenon leading to a fatigue failure of the assembly of piston and piston rings. The carried out durability investigation on a dual-fuel engine showed that, after relatively short time of engine operation at full load, there were observed failure cases typical for those induced by knocking combustion such as: damage of piston ring grooves, ring cracking as well as piston and cylinder scuffing.

\section{Unfavourable effects resulting from knocking combustion in a dual-fuel engine}

For many years in the Department of Automobiles and Internal Combustion Engines there are carried out investigations oriented towards prevention of the occurrence of knocking combustion. During laboratory tests, the process of combustion is being controlled with a knock sensor placed in the combustion chamber. During field investigations, engine head vibrations are registered (in a similar mode as in the spark-ignition engine) to detect knocking combustion. The range of knocking combustion is determined on the basis of the registered spectrum and, subsequently, the steering system changes regulating parameters to leave the range dangerous for engine durability. Exemplary results of investigation carried out by A. Różycki are presented in Fig. 6.

\section{Conclusions}

1. A dual-fuel engine is characterised by improved overall efficiency and the same achieved torque in comparison to the standard fuelling mode. Improvement in the overall efficiency results from the improvement of thermal efficiency
Zarejestrowane charakterystyki zestawiono na rys. 4.

Analiza zamieszczonych na wykresach przebiegów zmienności wartości (dP/d $\alpha)$ max wykazuje, że w obszarze obciążeń zbliżonych do maksymalnych silnik dwupaliwowy charakteryzuje się zdecydowanie wyższymi wartościami tego parametru w porównaniu z przypadkiem zasilania standardowego (w niektórych przypadkach nawet ponad dwukrotnie).

a)

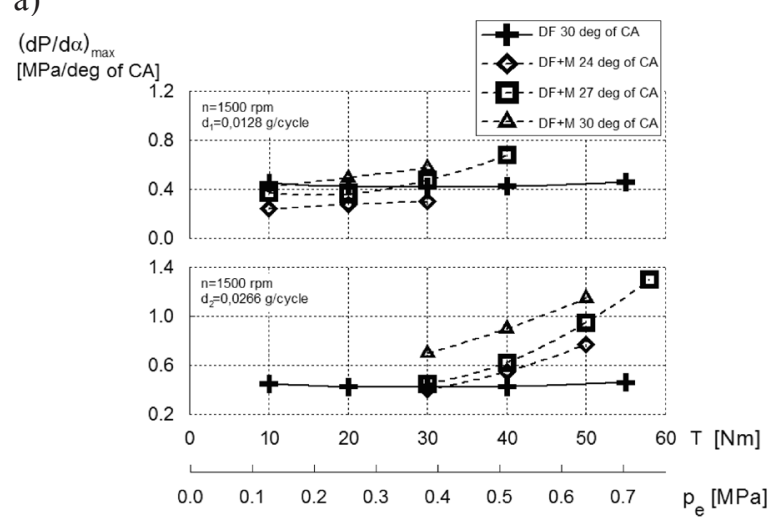

b)

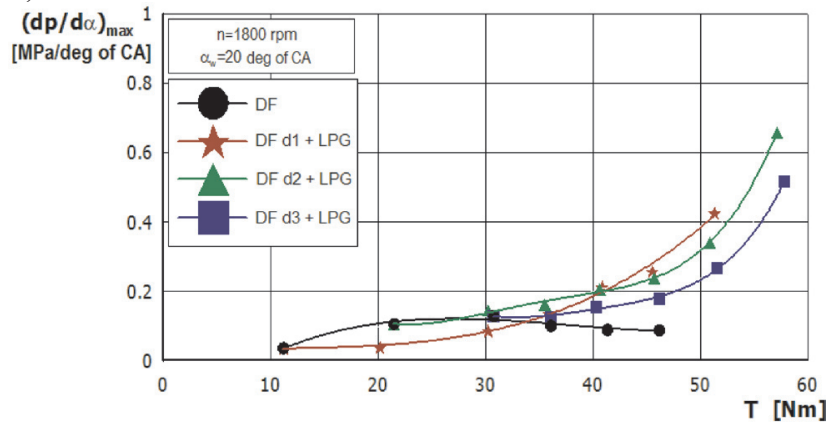

c)

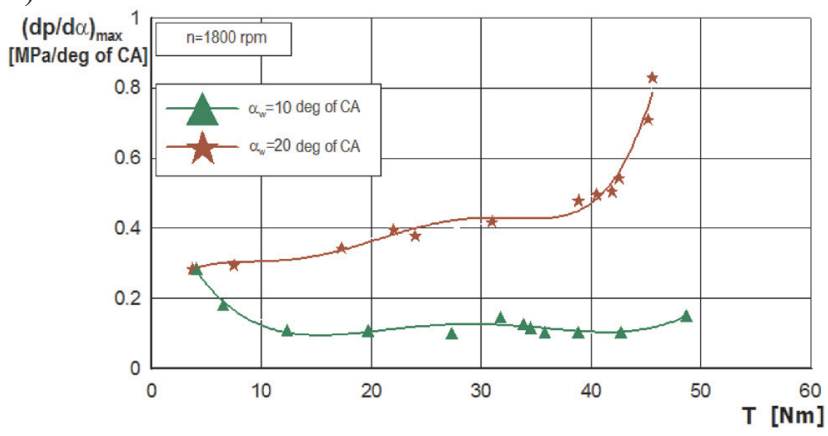

Fig. 4. Variability of the maximum rate of pressure rise versus engine load $(\mathrm{dP} / \mathrm{d} \alpha)_{\max }[\mathrm{MPa} / \mathrm{deg}$ of $\mathrm{CA}]=\mathrm{f}(\mathrm{T})[\mathrm{N} \cdot \mathrm{m}]$ for the above-described fuelling modes: a) engine fuelled mainly with methanol [9], b) engine fuelled mainly with LPG via mixer [11], c) engine fuelled mainly with LPG via an injection into the intake manifold [12]

Rys. 4. Zmienność maksymalnej szybkości narastania ciśnienia w funkcji obciązenia silnika $(d P / d \alpha)_{\max }\left[M P a /{ }^{\circ} \mathrm{OWK}\right]=f(M)[N \cdot m]$ dla opisanych przypadków zasilania silnika: a) silnik zasilany głównie metanolem [9], b) silnik zasilany głównie LPG poprzez mieszalnik [11], c) silnik zasilany głównie LPG poprzez wtrysk do kolektora dolotowego

Należy podkreślić, że efekt ten jest niepożądanym następstwem przyjętego systemu spalania, w którym homoge- 

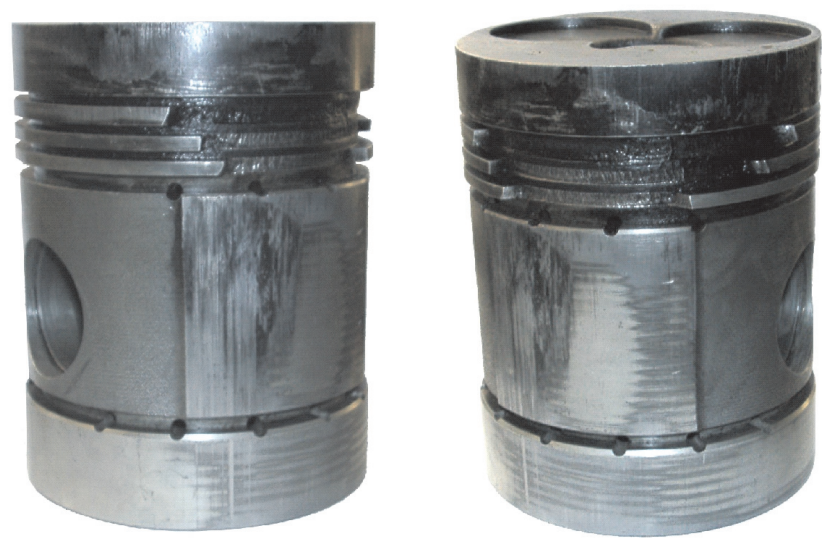

Fig. 5. Piston of a dual-fuel engine fuelled mainly with LPG and damaged in result of operation over the range of knocking combustion.

There are seen a damage of three piston ring grooves and traces of scuffing on the piston skirt [11]

Rys. 5. Tłok silnika zasilanego dwupaliwowo zasilanego głównie LPG uszkodzonego wskutek pracy w obszarze twardego spalania. Widoczne wyłamanie trzech pólek pierścieni uszczelniających oraz ślad zatarcia na powierzchni prowadzacej [11] niczna mieszanina paliwa głównego z powietrzem z dużą dynamiką podejmuje proces spalania od zainicjowanego wcześniej procesu spalania dawki oleju napędowego w znacznej objętości komory spalania. Efekt ten jest wyraźnie słyszalny jako „twarda” praca silnika. Pojawienie się spalania stukowego w obszarze obciążeń wyższych ogranicza możliwość dalszego zwiększenia obciążenia silnika. Staje się granicą dla osiągów silnika i jest zjawiskiem niebezpiecznym prowadzącym do zmęczeniowego zużycia zespołu tłoka i pierścieni tłokowych. Prowadzone badania trwałościowe silnika dwupaliwowego wykazały, że po stosunkowo niedługim czasie pracy silnika przy pełnym obciążeniu silnika dwupaliwowego pojawiają się awarie charakterystyczne dla efektów spalania stukowego, polegające na wyłamaniu półek podpierścieniowych, pękaniu pierścieni i zacieraniu tłoka i cylindra (rys. 5).

\section{Efekty niekorzystne wynikające ze spalania stukowego w silniku dwupaliwowym}

W Zakładzie Pojazdów i Silników Spalinowych od szeregu lat prowadzone są badania zmierzające do odsunięcia niebezpieczeństwa występowania spalania stukowego. Proces
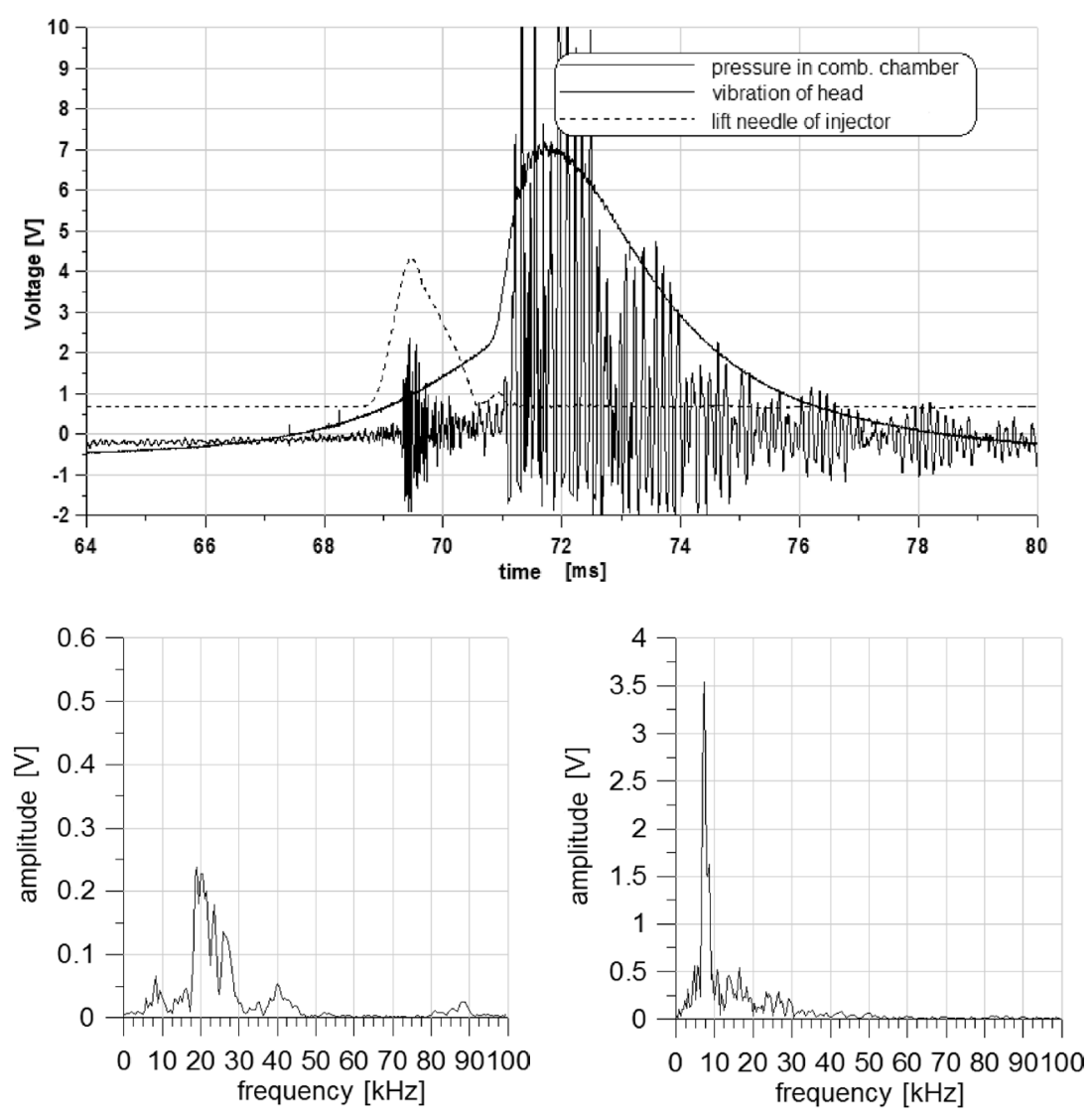

Fig. 6. Plots registered at the engine speed of $1800 \mathrm{rpm}$ and the load which evokes knocking combustion: a) runs of: cylinder pressure, pressure in the injection line, injection nozzle lift, engine head vibrations and their spectral analysis: b) in the range of 69-71 ms - fuel injection period, c) in the range of 71-73 ms - initial phase of combustion [14]

Rys. 6. Wykresy przedstawiające zarejestrowane przy prędkości obrotowej silnika $1800 \mathrm{obr} / \mathrm{min}$ i obciążeniu, przy którym występuje zjawisko stuku: a) zmiany ciśnienia $w$ cylindrze, zmiany ciśnienia $w$ przewodzie wtryskowym, przebieg wzniosu iglicy wtryskiwacza i drgania głowicy oraz analizę widmowa drgań głowicy: b) w zakresie 69-71 ms-okres wtrysku paliwa, c) w zakresie 71-73 ms - faza początkowa spalania [14] spalania kontrolowany jest w warunkach badań laboratoryjnych czujnikiem spalania stukowego zabudowanym w komorze spalania. W warunkach eksploatacyjnych dla zidentyfikowania występowania spalania stukowego prowadzona jest rejestracja drgań głowicy (podobnie jak w silniku o zapłonie iskrowym). Na podstawie zarejestrowanego widma drgań może być określony obszar występowania spalania stukowego i na tej podstawie system sterowania dokonuje zmiany parametrów regulacyjnych, tak by wyjść poza ten niebezpieczny dla trwałości silnika obszar. Przykładowe wyniki badań prowadzonych przez dr inż. Andrzeja Różyckiego przedstawia rys. 6.

\section{Wnioski}

1. Silnik dwupaliwowy charakteryzuje się poprawą sprawności ogólnej i zachowaniem osiąganego momentu obrotowego w porównaniu z wersją zasilaną standardowo. Poprawa sprawności ogólnej wynika z poprawy sprawności cieplnej silnika w efekcie przybliżenia procesu spalania do obserwowanego w silnikach HCCI spalania objętościowego.

2. Obserwowany wzrost zawartości $\mathrm{CO}$ i HC w obszarze obciążeń częściowych jest spowodowany niecałkowitym i niezupełnym spalaniem paliwa zasadniczego (szczególnie w obszarach komory spalania niespenetrowanych strugą płonącego oleju napędowego) a także zjawiskiem wygaszania płomienia pomiędzy denkiem 
resulting from approaching by the combustion process the volumetric mode observed in HCCI engines.

2. The observed increase of $\mathrm{CO}$ and $\mathrm{HC}$ emissions over the range of partial loads results from incomplete combustion of the main fuel (particularly in the zones of combustion chamber which are beyond the zone of burning diesel fuel stream) as well as from extinguishing the flame in the zone between piston surface and cylinder head plane distant from the combustion chamber in the piston. Such an explanation is also confirmed by the course of specific energy consumption (engine efficiency).

3. The observed decrease of $\mathrm{NO}_{x}$ emission over the range of partial loads seems to result from incomplete combustion described in point 2. Increase of $\mathrm{NO}_{\mathrm{x}}$ emission over the range of full loads is most likely caused by increased combustion temperature at high maximum pressures resulting from high rates of pressure rise.

4. Unfavourable effect of knocking combustion results from the occurrence of pressure rise in the process of combustion and rapid autoignition of the air - main fuel mixture beyond the zone of burning diesel fuel stream. Prevention of this phenomenon is possible by continuous registration of engine head vibrations. To solve this problem there is carried on investigation within the project granted by Ministry of Science and Higher Education No. N504301237. Results of investigation are presented by A. Różycki as well. tłoka a głowicą odległym od komory spalania w tłoku. Potwierdza to także charakter przebiegu zużycia jednostkowego energii (sprawności silnika).

3. Obserwowany zmniejszenia zawartości $\mathrm{NO}_{\mathrm{x}}$ w spalinach w obszarze obciążeń częściowych wydaje się być efektem opisanego w pkt. 6.2 niezupełnego i niecałkowitego spalania. Wzrost emisji NO w obszarze obciążeń całkowitych to najprawdopodobniej efekt wzrostu temperatur w procesie spalania przy dużych ciśnieniach maksymalnych wynikających z dużych szybkości narastania tego parametru (rys. 4).

4. Niekorzystny efekt spalania stukowego jest efektem pojawienia się dużych przyrostów ciśnienia w procesie spalania i gwałtownego samozapłonu homogenicznej mieszaniny paliwa głównego i powietrza w obszarze poza płonącą strugą dawki oleju napędowego. Zapobieżeniu temu zjawisku jest możliwe na drodze ciągłej rejestracji drgań głowicy. W tym zakresie prowadzone są badania w ramach projektu zleconego przez Ministra Nauki i Szkolnictwa Wyższego Nr N504301237, których wyniki prezentowane są także przez dr inż. Andrzeja Różyckiego.

Paper reviewed/Artykut recenzowany

\section{Bibliography/Literatura}

[1] Khandare S. S., Garg R. D., Gaur R. R.: Investigation on the use of solid fuels for diesel engine. SAE Paper. 872094.

[2] Kusaka J., Daisho Y., Kihara R., Saito T.: Combustion and exhaust gas emission characteristics of a diesel engine dualfuelled with natural gas. The Fourth International Symposium COMODIA'98 Proceedings, Japan, Koyoto 1998.

[3] Jothi N.K.M., Nagarajan G., Renganarayanan S.: Experimental studies on homogeneous charge CI engine fuelled with LPG using DEE as an ignition enhancer. Renewable Energy, Elsevier vol. 32 (2007), pp. 1581-1593.

[4] Furutani M., Ohta Y., Kono M., Hasegawa M.: An ultra-lean premixed compression-ignition engine concept and its characteristics. The Fourth International Symposium COMODIA ‘98 Proceedings, Japan, Kyoto 1998.

[5] Stelmasiak Z.: Effect of the magnitude of diesel fuel initial dose on the work parameters of dual-fuel engine fed with diesel fuel and natural gas. Journal of Kones - Internal Combustion Engines, Vol. 8, No. 3-4, 2001.

[6] Clark N.N., Atkinson Chr.M., Atkinson R.J.: Optimized emission reduction strategies for dual fuel compression ignition engines running on natural gas and diesel. www.cemr.wvu. edu/englab/projects/saturn.htlm, 2002.

[7] Gebert K., Beck N.J., Barkhimer R.L.: Strategies to improve combustion and emission characteristics of dual-fuel pilotignited natural gas engines. SAE Paper 971712, 1997.

[8] Chen Z., Konno M., Goto S.: Study on homogeneous premixed charge CI engine fuelled with LPG. JSAE, Elsevier vol. 22 (2001), pp. 265-270.
[9] Luft S.: Studium silnika o zapłonie samoczynnym zasilanego alkoholem metylowym. Wydawnictwo Politechniki Radomskiej, Monografia Nr 29, 1997.

[10] Takatsuto R., IgarashiT., Iida N.: Auto ignition and combustion of DME and n-butane /air mixtures in homogeneous charge compression ignition engine. The Fourth International Symposium COMODIA'98 Proceedings, Japan, Kyoto 1998.

[11] Luft S.: Dwupaliwowy silnik o zapłonie samoczynnym zasilany mieszaniną gazów propan-butan (LPG) i olejem napędowym. Wydawnictwo Politechniki Radomskiej, Monografia $\mathrm{Nr}$ 54, 2002.

[12] Luft S.: Dwupaliwowy silnik o zapłonie samoczynnym z wtryskiem ciekłego LPG do kolektora dolotowego. Wydawnictwo Politechniki Radomskiej, Monografia Nr 103, 2007.

[13] Stelmasiak Z.: Wpływ niektórych parametrów regulacyjnych na osiągi dwupaliwowego silnika o zapłonie samoczynnym zasilanego gazem ziemnym. Zeszyty Naukowe Politechniki Częstochowskiej Nr 155, Mechanika Nr 25, 2003.

[14] Różycki A.: Drgania głowicy silnika wysokoprężnego zasilanego dwupaliwowo. Archiwum Motoryzacji, Wydawnictwo Naukowe Polskiego Towarzystwa Motoryzacji, Nr 2/2005.

Prof. Sławomir Luft, DSc., DEng. - Professor at the Faculty of Mechanical Engineering, Technical University of Radom.

Prof. Stawomir Luft - profesor na Wydziale Mechanicznym Politechniki Radomskiej.

e-mail: s.luft@pr.radom.pl 